\title{
The Effects of (Social) Media on Revolutions - Perspectives from Egypt and the Arab Spring
}

\author{
Christian Sturm ${ }^{1}$ and Hossam Amer ${ }^{2}$ \\ ${ }^{1}$ Hamm-Lippstadt University of Applied Sciences \\ christian.sturmahshl.de \\ ${ }^{2}$ The German University in Cairo, Egypt \\ hossam.amer12@gmail.com
}

\begin{abstract}
The Arab Spring has been titled as "social media revolution". While there is no doubt that Facebook and twitter contributed significantly to the course of events, its role can only be understood when put into a broader technological and historical context. Therefore, we looked at the role of technology during prior revolutions such as the French Revolution in 1789. It turns out that media technology has played an important supportive role in social and political movements throughout history. The changing characteristic, however, has always been the speed of information diffusion. Therefore, it is concluded that social media should be seen as supportive but not exclusively responsible for the events of the Arab Spring.
\end{abstract}

Keywords: Social media, society, revolution, evolution, twitter, Facebook, democratization, media technology, Arab Spring, French Revolution.

\section{Introduction}

It is indisputable that the recent developments in the Middle East are of global magnitude. The so-called "Arab Spring" got worldwide social, political and media attention due to its characteristics and connectedness with local, regional and international interests. From the starting point in Tunisia and spreading over to Egypt and other countries, people are revolting against suppressive forms of government and leadership. One of the biggest achievements consists in an emerging public dialogue within the societies and different social groups of the Middle East about the governing principles of everyday life. This has been possible through the ousting of long-term presidents in the region. Social media such as Facebook and twitter was mentioned by researchers and the press as an enabler for these happenings. Therefore, what happened in the Middle East is often referred to as "social media revolution" [1].

Nowadays, the use of social media is an established component for public and private communication in the region. The Egyptian use of these services increased through the January $25^{\text {th }}$ revolution tremendously. It moved mainstream for a lot of people. The majority, however, is still not connected due to a high level of illiteracy and a lack of accessibility to information technology. 
Nevertheless, the importance of social media cannot be denied. Therefore, a lot of groups are debating its effects on revolutions. Some argue that the Internet is a doubleedged sword that could be a potential tool for suppression [2]. Others clearly state that social media did have a significant role beyond being a source of news: "We use Facebook to schedule the protests, Twitter to coordinate, and YouTube to tell the world" [3].

The actual role of social media, however, whether supporting or causing the developments during the Arab Spring, can only be determined by putting the events into a broader context. Thus, the comparison with historic social developments on the one hand and technological advances on the other hand will be the focal point for the following chapters in order to see if the Arab Spring can be named a "social media revolution".

\section{2 (Media) Revolutions}

\subsection{Revolutions}

The concept of "revolution" is extremely diverse without a unified definition. Its Latin origin "revolution" means "turn around". This refers to "change" in the broadest sense. This change can be social, political, technical, cultural, psychological, personal or any other domain that would change fundamental principles. In the context of this paper, we look at revolutions of political and social systems. Tanter and Midlarsky [14] define four different types of revolutions based on characteristics such as mass participation, duration, domestic violence and intensions of the insurgents. Table 1 provides an overview of the types and their respective characteristics.

Table 1. Characteristics of revolutions according to Tanter and Midlarsky [14]

\begin{tabular}{|c|c|c|c|c|}
\hline $\begin{array}{c}\text { Type of } \\
\text { revolution }\end{array}$ & $\begin{array}{c}\text { Mass } \\
\text { participation }\end{array}$ & Duration & $\begin{array}{c}\text { Domestic } \\
\text { violence }\end{array}$ & $\begin{array}{c}\text { Intentions of } \\
\text { insurgents }\end{array}$ \\
\hline Mass revolution & High & Long & High & $\begin{array}{l}\text { Fundamental } \\
\text { changes in the } \\
\text { structure of politi- } \\
\text { cal authority and } \\
\text { social system }\end{array}$ \\
\hline $\begin{array}{l}\text { Revolutionary } \\
\text { coup }\end{array}$ & Low & $\begin{array}{l}\text { Short to } \\
\text { moderate }\end{array}$ & $\begin{array}{l}\text { Low to } \\
\text { moderate }\end{array}$ & $\begin{array}{l}\text { Fundamental } \\
\text { changes in the } \\
\text { structure of politi- } \\
\text { cal authority and } \\
\text { possibly some } \\
\text { change in the so- } \\
\text { cial system }\end{array}$ \\
\hline Reform coup & Very low & $\begin{array}{c}\text { Short, } \\
\text { sometimes } \\
\text { moderate }\end{array}$ & Low & $\begin{array}{l}\text { Moderate changes } \\
\text { in the structure of } \\
\text { political authority }\end{array}$ \\
\hline Palace revolution & None & Very short & $\begin{array}{l}\text { Virtually } \\
\text { none }\end{array}$ & $\begin{array}{c}\text { Virtually no } \\
\text { change }\end{array}$ \\
\hline
\end{tabular}


According to Tanter and Midlarsky [14], the French Revolution in 1789 as well as the German Revolution in 1848 could be categorized as mass revolutions. Revolutionary coups would be found in Turkey (1919), Germany (1933) and Egypt (1952). Argentina (1955), Syria (1956) and Pakistan (1958) experienced a reform coup while Venezuela and Brazil had a palace revolution in 1948 and 1955 respectively.

\subsection{Media in Revolutions}

Based on the schema for the categorization of revolutions mentioned above, the Arab Spring can be defined as a mass revolution. As such, it is clearly not an individual but a group phenomenon. Like every mass movement, communication between the different groups and actors plays a central role for the course of events. Due to its very nature, this mass communication is only possible if it is mediated in order to overcome the limitations of time and space. Therefore, it can be concluded that media technology tend to play an important role for mass revolutions in order to address these challenges.

Already the French Revolution "can be considered an epochal media event" [4]. The pre-industrialized printing press allowed the distribution of information in an amount and speed not known before. Tens of thousands of pamphlets were printed and distributed. The number of newspapers grew from just a couple "to over three hundred weekly and daily newspapers between 1789 and 1790" [4], while most of them were produced by individuals. This was possible only due to the low production costs. It is estimated that the total number of newspapers created during the revolution adds up to around 1,600 [4]. A lot of content was transmitted as well with printed pictures due to an illiteracy rate of more than $50 \%$ for men and more than $70 \%$ for women at the time [5].

In conclusion, media technology can be seen as an important component for the information and mobilization of the masses already in the $18^{\text {th }}$ century. Further examples for this supporting role from recent history include the so-called twitter revolution in Iran [6] and the Multimedia or SMS revolt in the Philippines [7]. They show clearly that access as well as low cost of production and distribution account for possible easy dissemination of new ideas by individuals. Normally, television would not be considered as having these advantages. The protesters in Eastern Germany, however, were able to use the Western television and other media for informing the population of the former GDR on the protests that emerged increasingly in 1989 [8].

In summary, it can be stated that media technology, easy access and low entry barriers played always an important role in mass revolutions throughout history. It is not a unique consequence of the latest developments in information and communication technology. Therefore, the recent events in the Middle East might have happened sooner or later with a different course of events even without the use of social media.

\subsection{Revolutionary Timelines}

Looking at mass revolutions in the last centuries, it turns out that they are composed of single events and actions of different magnitudes. Although the Egyptian revolution is 
referred to as the "January $25^{\text {th }}$ Revolution", there is a set of previous events leading up to it [9]. The same can be observed for the time after the presidents of the region were ousted. The process of negotiating the new principle foundations of everyday life is contains violent events with a smaller magnitude than the main happening. This can be seen in both successful revolutions such as the French Revolution that peaked in 1789 and not successful ones such as the German Revolution in 1848.

Figure 1 shows a smoothed graphical representation of such a typical course of events. The horizontal axis is considered the timeline from left to right while the vertical axis refers to actions of opposing parties with different magnitudes. In the case of the Egyptian or Tunisian revolution, the central peak would relate to the ousting of the president. The waves on the left are the events and counter-events preceding the ousting. The waves after the peak on the right refer to events that represent the struggle of power between different parties. Interestingly, this course of events can be represented mathematically by the formula:

$$
f(x)=\sin (x) / x
$$

The following chapter is going to look at possibilities to describe different mass revolutions throughout the history by this formula.

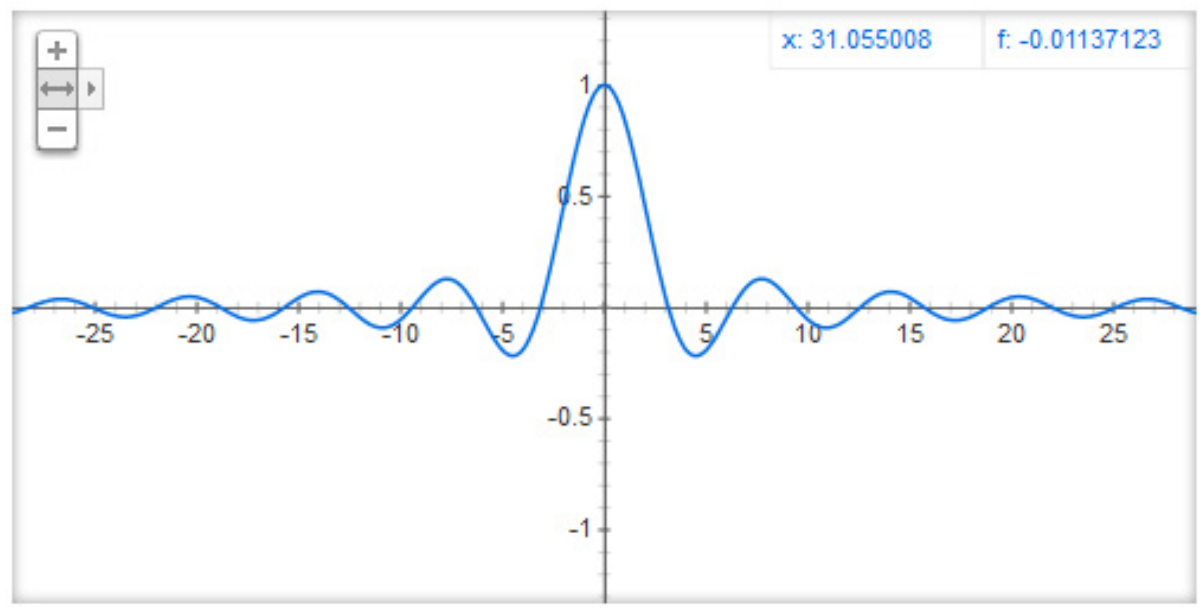

Fig. 1. Graphical representation of the course of revolutions [as displayed by google.com searching for $\mathrm{f}(\mathrm{x})=(\sin (\mathrm{x}) / \mathrm{x})$ ]

\section{The Changing Characteristic of Media Technology}

The previous chapter concludes that media technology was always an important component of mass revolutions. So what has changed since the French Revolution? What are the differences between the technology available then and now? 
It has been argued that mediated communication is essential for dissimilating information and ideas to the masses. Looking at the historical developments of other domains helps to understand the most important changing characteristic.

The sector of transportation saw tremendous changes in the last centuries. The daily distance possible to travel in the $19^{\text {th }}$ century with a carriage drawn by horses was about forty miles maximum [10]. Today's high speed trains allow traveling this distance in $12 \mathrm{~min}$ while it takes a plane about 4 minutes only. Besides the increased comfort, the speed of transportation is 165 times faster than centuries ago.

The changes that occurred in the business and financial sector are even more drastic. Before the invention of the telegraph, it took traders at the stock exchange between days and weeks in order to finish a transaction. The New York Stock Exchange today is able to close a transaction in $0.5 \mathrm{~ms}$ [11]. The factor for the increase in speed is of hundreds of millions.

The distribution of news did undergo a similar development. According to [12] it took from 21 October 1805 to 6 November 1805 to publish the Battle of Trafalgar in the London Gazette. Similarly "the French invasion of Russia on 24 June 1812" was "published in The Times on 13 July 1812". Nowadays, a tweet or post on Facebook is published in a couple of seconds. The combination of influencers with a lot of connections and average users that "quickly convey the information from one neighbor to another" [13] results in the phenomenon of spreading the information faster than established media would do.

In summary, speed of distribution can be seen as the changing characteristic of technology. Taking both the changes in speed and the mathematical representation of revolutions presented in the previous chapter, it even might be possible to come up with a formal way of describing the course of revolutionary events by taking into account various factors such as speed of communication provided by type of media technology, number of participants and intentions of insurgents.

\section{$4 \quad$ What's Next?}

The diffusion of activities, statements and information increased tremendously through the usage of social networks such as Facebook and twitter. Compared to the high-speed trading executed at the stock markets, however, it is still in its infancy. The digitalization of the message with cameras and keyboards together with the distribution is still in the realm of seconds or even minutes. Projecting the latest technological advances in the fields of ubiquitous computing and augmented reality, however, could lead to a boost in the speed of diffusion that would enable types of revolutions not yet known.

A simple scenario combining the Google Glasses with an iWatch measuring and combining a huge set of data could lead to a true distribution of perceptions, emotions and happenings in real-time. Thus, if a huge amount of people share and synchronize such information, the network effect might be bigger and more influential than all the mass revolutions seen before. 


\section{Conclusion}

This paper looked at the role of media technology in the recent social and political developments in the Middle East. The so-called "social media revolution" has been put into a broader technological and historical context in order to gain a deeper understanding of its impact. It has been shown that principal characteristics such as easy access and low entry barriers in terms of costs were already one of the main factors that support the developments in the French Revolution in 1789. The only basic element that changed constantly over the centuries was the speed of creation and transmission of information. Therefore, it is argued that the Arab Spring should rather be called a movement supported by media technology rather than a "social media revolution". The events would not have happened without the social and political reality on the ground. This reality, however, could have led to the same movement even without social media involved.

\section{References}

1. Tayler, K.: Arab Spring really was social media revolution. TG Daily (2011), http: / /www.tgdaily.com/software-features/58426-arab-springreally-was-social-media-revolution (last access: March 1, 2013)

2. Shanthi, K., Taylor, B.: Open Networks, Closed Regimes: The Impact of the Internet on Authoritarian Rule. Carnegie Endowment (2003)

3. Chebib, N., Sohail, R.: The Reasons Social Media Contributed to the 2011 Egyptian Revolution. International Journal of Business Research and Management (2011)

4. Reichardt, R.: The French Revolution as a European Media Event (2012), http: / /www. ieg-ego.eu/en/threads/european-media/ european-media-events/rolf-reichardt-the-french-revolutionas-a-european-media-event (last access: March 1, 2013)

5. Histoire de la scolarisation en France, http://fr.vikidia.org/wiki/ Histoire_de_la_scolarisation_en_France (last access: March 1, 2013)

6. Burns, A., Eltham, B.: Twitter Free Iran: an Evaluation of Twitter's Role in Public Diplomacy and Information Operations in Iran's 2009 Election Crisis. In: Communications Policy \& Research Forum 2009, November 19-20. University of Technology, Sydney (2009)

7. Coronel, S.: The media, the market and democracy: The case of the Philipines. Javnost=The Public 8(2), 109-124 (2001)

8. Friedensgebete und Montagsdmonstrationen Bundeszentrale für politische Bildung und Robert-Havemann-Gesellschaft e.V. (2008), http: / /www.jugendopposition.de/index.php?id=638 (last access: March 1, 2013)

9. Wolman, D.: The Digital Road to Egypt's Revolution. The New York Times (2012), http: / /www. nytimes.com/interactive/2012/02/12/opinion/ sunday/20120212-tahir-timeline.html (last access: March 1, 2013)

10. Ritter, W.: Fremdenverkehr in Europa. Eine wirtschafts- und sozialgepgraphische Untersuchung über Reisen und Urlaubsaufenthalte der Beweohner Europas. Leiden (1966) 
11. Schewe, P.: Relativistic trading: The speed of light isn't fast enough for some market transactions (2010), http:/ / phys . org/news / 2010-11-relativistic-isntfast-transactions.html (last access: March 1, 2013)

12. How fast did news travel? http://www.historyhouse.co.uk/articles/ speed_of_news.html (last access: March 1, 2013)

13. Doerr, B., Fouz, M., Friedrich, T.: Why Rumors Spread Fast in Social Networks. Communications of the ACM 55, 70-75 (2012)

14. Tanter, R., Midlarsky, M.: A theory of revolution. The Journal of Conflict Resolution 11(3), 264-280 (1967) 